\title{
Historical Development of Origins Research
}

\author{
Antonio Lazcano \\ Facultad de Ciencias, Universidad Nacional Autónoma de México, Apdo. Postal 70-407, \\ Cd. Universitaria, 04510 México D.F., Mexico \\ Correspondence: alar@correo.unam.mx
}

Following the publication of the Origin of Species in 1859, many naturalists adopted the idea that living organisms were the historical outcome of gradual transformation of lifeless matter. These views soon merged with the developments of biochemistry and cell biology and led to proposals in which the origin of protoplasm was equated with the origin of life. The heterotrophic origin of life proposed by Oparin and Haldane in the 1920s was part of this tradition, which Oparin enriched by transforming the discussion of the emergence of the first cells into a workable multidisciplinary research program.

On the other hand, the scientific trend toward understanding biological phenomena at the molecular level led authors like Troland, Muller, and others to propose that single molecules or viruses represented primordial living systems. The contrast between these opposing views on the origin of life represents not only contrasting views of the nature of life itself, but also major ideological discussions that reached a surprising intensity in the years following Stanley Miller's seminal result which showed the ease with which organic compounds of biochemical significance could be synthesized under putative primitive conditions. In fact, during the years following the Miller experiment, attempts to understand the origin of life were strongly influenced by research on DNA replication and protein biosynthesis, and, in socio-political terms, by the atmosphere created by Cold War tensions.

The catalytic versatility of RNA molecules clearly merits a critical reappraisal of Muller's viewpoint. However, the discovery of ribozymes does not imply that autocatalytic nucleic acid molecules ready to be used as primordial genes were floating in the primitive oceans, or that the RNA world emerged completely assembled from simple precursors present in the prebiotic soup. The evidence supporting the presence of a wide range of organic molecules on the primitive Earth, including membrane-forming compounds, suggests that the evolution of membrane-bounded molecular systems preceded cellular life on our planet, and that life is the evolutionary outcome of a process, not of a single, fortuitous event.

t is generally assumed that early philosophers and naturalists appealed to spontaneous generation to explain the origin of life, but in fact, the possibility of life emerging directly from nonliving matter was seen at first as a nonsexual reproductive mechanism. This changed with the transformist views developed by Erasmus Darwin, Georges Louis Leclerc de Buffon, and,

Editors: David Deamer and Jack W. Szostak

Additional Perspectives on The Origins of Life available at www.cshperspectives.org

Copyright (C) 2010 Cold Spring Harbor Laboratory Press; all rights reserved; doi: 10.1101/cshperspect.a002089

Cite this article as Cold Spring Harb Perspect Biol 2010;2:a002089 


\section{A. Lazcano}

most importantly, by Jean-Baptiste de Lamarck, all of whom invoked spontaneous generation as the mechanism that led to the emergence of life, and not just its reproduction. "Nature, by means of of heat, light, electricity and moisture", wrote Lamarck in 1809, "forms direct or spontaneous generation at that extremity of each kingdom of living bodies, where the simplest of these bodies are found".

Like his predecessors, Charles Darwin surmised that plants and animals arose naturally from some primordial nonliving matter. As early as 1837 he wrote in his Second Notebook that "the intimate relation of Life with laws of chemical combination, \& the universality of latter render spontaneous generation not improbable." However, Darwin included few statements about the origin of life in his books. He avoided the issue in the Origin of Species, in which he only wrote "... I should infer from analogy that probably all organic beings which have ever lived on this Earth have descended from some one primordial form, into which life was first breathed" (Peretó et al. 2009).

Darwin added few remarks on the origin of life his book, and his reluctance surprised many of his friends and followers. In his monograph on the radiolaria, Haeckel wrote "The chief defect of the Darwinian theory is that it throws no light on the origin of the primitive organism - probably a simple cell — from which all the others have descended. When Darwin assumes a special creative act for this first species, he is not consistent, and, I think, not quite sincere ..." (Haeckel 1862).

Twelve years after the first publication of the Origin of Species, Darwin wrote the now famous letter to his friend Hooker in which the idea of a "warm little pond" was included. Mailed on February 1st, 1871, it stated that "It is often said that all the conditions for the first production of a living organism are now present, which could ever have been present. But if (and Oh! what a big if!) we could conceive in some warm little pond with all sorts of ammonia and phosphoric salts-light, heat, electricity \&c. present, that a proteine compound was chemically formed, ready to undergo still more complex changes, at the present day such matter $\mathrm{w}^{\mathrm{d}}$ be instantly devoured, or absorbed, which would not have been the case before living creatures were formed." Although Darwin refrained from any further public statements on how life may have appeared, his views established the framework that would lead to a number of attempts to explain the origin of life by introducing principles of historical explanation (Peretó et al. 2009). Here I will describe this history, and how it is guiding current research into the question of life's origins.

\section{BACKGROUND}

\section{The Search for the Physicochemical Basis of Life}

In 1805 the German naturalist Lorenz Oken wrote a small booklet titled The Creation, in which stated that "all organic beings originate from and consist of vesicles of cells." Several decades later the jellylike, water-insoluble substance that was found inside all cells was termed "protoplasm" by the physician Johann E. Purkinje and the botanist Hugo von Mohl, who like others argued that it was the basic physicochemical component of life. This was followed by Thomas Graham's 1861 proposal that the protoplasm was a colloid formed by a homogenous, proteinaceous substance, which was understood by many as implying, as Thomas Henry Huxley would write a few years later, that the basic traits of life could be understood in terms of the chemical and physical properties of the molecules that made up protoplasm.

The birth and development of organic chemistry as a prominent scientific field very rapidly helped to bridge the gap separating organisms from the nonliving, paving the way to biochemistry. In 1827 Berzelius had written that "art cannot combine the elements of inorganic matter in the manner of living nature", but one year later his friend and former student Friedich Wöhler showed that urea could be formed in high yield by heating ammonium cyanate "without the need of an animal kidney" (Leicester 1974).

Wöhler's work represented the first synthesis of an organic compound from inorganic 
starting materials and signals the tremendous advances in organic chemistry that would play a key role in our understanding of biology. Although it was not immediately recognized as such, a new era in chemical research had been begun: in 1850 Adolph Strecker achieved the laboratory synthesis of alanine from a mixture of acetaldehyde, ammonia and hydrogen cyanide. This was followed by the experiments of Alexander M. Butlerov showing that the treatment of formaldehyde with strong alkaline catalysts, such as calcium hydroxide, leads to the synthesis of sugars.

The laboratory synthesis of biochemical compounds was soon extended to include more complex experimental settings, some of which attempted to explain biological synthesis. For example, in 1877 Mendeleyeev, who was skeptical of the biological origin of oil, reported the synthesis of hydrocarbons from hot metallic carbides and water. By the end of the 19th century a large amount of research on organic synthesis had been performed, which showed the abiotic formation of fatty acids and sugars using electric discharges with various gas mixtures. This trend continued into the 20th century by Walther Löb, Oskar Baudish, and others, who reported the synthesis of amino acids by exposing wet formamide $\left(\mathrm{CHO}-\mathrm{NH}_{2}\right)$ to a silent electrical discharge and to UV light (cf. Bada and Lazcano 2003).

In retrospect, these efforts to produce simple organic compounds heralded the dawn of what is termed today prebiotic chemistry. However, there are no indications that the researchers who performed these studies were interested in how life began on Earth, or in the synthesis of biochemical molecules under primitive conditions. It was generally assumed that that the first living beings had been autotrophic, plantlike organisms, so the abiotic synthesis of organic compounds did not appear to be a necessary prerequisite for the emergence of life. These organic syntheses were not conceived as laboratory simulations of Darwin's warm little pond, but rather as attempts to understand the autotrophic mechanisms of nitrogen assimilation and $\mathrm{CO}_{2}$ fixation in green plants.
Historical Development of Origins Research

Spontaneous Generation or Cosmic Origins?

The Origin of Species was published in 1859, the verysame year in which Pasteur began the experiments that would lead him to disprove spontaneous generation of living organisms. His results had implications that went well beyond the limits of academia. Since the times of Lamarck and Buffon, spontaneous generation had been associated in France not only with evolutionary theory but also with secular attitudes and radical political views. The publication in 1862 of the French translation The Origin of Species by the notorious atheist and republican Madame Clémence Royer rekindled the debate. Her version included a lengthy preface that was, in essence, a fierce attack against the Catholic Church, by then a powerful ally of Napoleon III. In such entangled atmosphere, spontaneous generation embodied not only support for evolution, but also a radical, anticlerical political stance (Farley 1977; Fry 2002; Strick 2009).

Pasteur was fully aware of the ideological implications of his discoveries. In a famous lecture delivered at La Sorbonne in 1864, he not only denied the possibility that inanimate matter could organize itself into living systems, but also stated that "what a victory for materialism if it could be affirmed that it rests on the established fact that matter organizes itself, takes on life itself; matter which has in it already all known forces. Ah! If we could add to it this other force which is called life ... what could be more natural than to deify such matter? Of what good would it be then to have recourse to the idea of a primordial creation? To what good the would be the idea of a Creator God? ... if we admit the idea of spontaneous generation, than it would not be surprising to assume that living beings "transformed themselves and climb from rank to rank, for example to insects after 10,000 years and no doubt to monkeys and man after 100,000 years" (cf. Farley 1977).

Regardless of their political ramifications, Pasteur's results made it difficult to advocate spontaneous generation as an explanation for the ultimate origin of life. As a result, a number of philosophers and naturalists promptly dismissed the study of the origins of life as senseless 


\section{A. Lazcano}

speculation, whereas the willful distortion of Pasteur's results by others raised vitalistic expectations once again. Several devoted materialists like Emil du Bois-Reymond, Karl von Nageli, and August Weismann continued to support the idea of spontaneous generation, but others, like Hermann von Helmholtz, felt that they could side-step the issue by assuming that viable microbes_- "cosmozoa" — had been delivered to the primitive Earth by meteorites, thus maintaining the significance of evolution.

Cosmozoa became an alternative for those unwilling to accept the idea of a nonmaterial basis for life, but also for staunch opponents of evolution like Lord Kelvin, who since 1871 had argued for the extraterrestrial origin of life. Toward the end of the 19th century, the belief that life on Earth had evolved from extraterrestrial organisms elicited a number of proposed mechanisms that could have transported microbes between planets, but little attention was given to the central issue of the actual origin of the life forms (Kamminga 1982; Fry 2002). With formidable disregard for plausibility, the panspermia hypothesis has been repeatedly proposed in a variety of contexts, but of course does not solve the problem of the origin of life, instead merely transferring its origin to another habitable planet in our galaxy.

\section{Life and the Single Molecule}

Not surprisingly, the idea that living organisms were the historical outcome of gradual transformation of lifeless matter became widespread soon after the publication of The Origin of Species. Despite their diversity, most of these explanations went unnoticed, in part because they were incomplete, speculative schemes largely devoid of direct evidence and not subject to fruitful experimental testing. Although some of these hypotheses considered life as an emergent feature of nature and attempted to understand its origin by introducing principles of historical explanation, the dominant view was that the first forms of life were structureless droplets of protoplasm endowed with the ability fix atmospheric $\mathrm{CO}_{2}$ and to use it with water to synthesize organic compounds.
The ideas of Jerome Alexander, Stephane Leduc, and Alfonso L. Herrera epitomize this trend. Like many of his contemporaries, the Mexican A.L. Herrera was convinced that life could be created in the laboratory, and proposed an autotrophic theory known as plasmogenesis. Herrera devoted more than $50 \mathrm{yr}$ to experimenting with different kinds of substances, attempting to "illustrate the physico chemical concomitants of life" (Herrera 1902). At first he used mixtures of water and oil (or gasoline) to understand the shape, size and movement of cell-like structures. He would later refined his ideas and, despite the academic isolation in which he worked, developed his theory of "plasmogeny," which attempted to explain the origin of primitive photosynthetic protoplasm. This led him to experiment with formaldehyde and hydrogen cyanide derivatives like $\mathrm{NH}_{4} \mathrm{SCN}$ (Herrera 1942), a combination that we now know produces sugars and highly colored polymers, which unfortunately he mistook for photosynthetic pigments (Perezgasga et al. 2003).

The rapid development of biochemistry and the characterization of an increasingly large number of proteins signaled the idea that life could be associated with specific enzymes and that submicroscopic colloidal aggregates or micelles could show the properties of life. Enzymes were seen as colloidal catalysts, which led to the hypothesis that entities smaller and simpler than protoplasm itself could be alive (cf. Fry 2006). In 1917 Felix D'Herelle discovered a self-propagating filterable "substance" that attacked and dissolved bacilli, which were later identified as bacteriophage viruses, and these supposedly simple submicroscopic particles were assumed to be primordial entities (D’Herelle 1926; Summers 1999).

Some investigators proposed even smaller structures as primordial. For instance, in a series of papers published between 1914 and 1917, the American physicist Leonard Troland suggested that the first living entity had been nothing more than a self-replicating enzymelike molecule that had suddenly appeared in early oceans. This primordial enzyme was assumed by Troland to be endowed with autocatalytic 
properties that allowed it to self-multiply, as well as having heterocatalytic abilities that could alter its surroundings, therefore giving rise to metabolism. Troland's hypothesis is hindered both by its highly reductionist nature and by the impossibility of empirical analysis of a proposal that depends on the chancelike association of a "living molecule." As summarized by Fry (2006), although Troland had originally proposed a primordial enzyme as the starting point of life, he modified his hypothesis to speak of a "genetic enzyme" which he eventually identified with nucleoproteins present in nuclei (Troland, 1914, 1916, 1917).

It did not take long for Hermann J. Muller, an American geneticist who would play an important role in the understanding of Mendelian heredity, to modify Troland's hypothesis and propose that the ancestral molecule had been, in fact, a gene. Even more explicitly than Troland, Muller argued that the first living material was formed abruptly and consisted of little more than a mutable gene, or set of genes, endowed with catalytic and autoreplicative properties, which, he hinted, were autotrophic (Muller 1922, 1926).

It is easy to understand Muller's proposal in terms of his commitment to Mendelian genetics. Muller was a founding member of Thomas Hunt Morgan's fly room in Columbia Uiversity, where he had spent several years working with Calvin Bridges, Alfred Sturtevant and Morgan himself, on the linear arrangement of genes in the Drosophila chromosomes (Carlson 1981). He had been pondering for some time on the autocatalytic properties of chromatin (Ravin 1977), and his appreciation of genetic mutation as the fundamental mechanism of evolutionary novelties developed at a time when the appeal of Darwin's ideas on the role of natural selection had diminished. Accordingly, given the appearance of a genetic material capable of replication, mutation and further replication of mutant forms, "evolution would automatically follow" (Pontecorvo 1982). Muller's explanation of the origin of life reveals a mutationist's attitude, not a Darwinian one.

Historical Development of Origins Research

Toward the Primitive Soup

In November 1923 a small book titled The Origin of Life was published in Moscow by the young Russian biochemist Alexander Ivanovich Oparin. Like many of his contemporaries, Oparin (1924) accepted the idea of a primordial protoplasm but proposed that life had been preceded by a lengthy period of abiotic syntheses and accumulation of organic compounds that had led to the accumulation of what we call today the primitive soup. Oparin's central thesis was that the first organisms to emerge in the anaerobic environment of the primitive Earth must have been heterotrophic bacteria.

As a young student at the University of Moscow, Oparin had joined the laboratory of Alexei N. Bakh, an eminent scientist and political figure at the Karpov Physicochemical Institute. There he worked on photosynthesis and, like most biochemists of his generation, quickly adopted the idea that metabolism was the outcome of oxidation and reduction reactions that were coupled inside cells. By then Oparin was also a convinced evolutionist. As an undergraduate he had attended the lectures given regularly by Kliment A. Tymiriazev, a renowed plant physiologist, agronomer, and the main advocate of Darwinism in Russia. Starting in 1865, Tymiriazev actively promoted Darwin's idea, an effort that would play a major role in the secularization of Russian society, and endeared him to both the liberal and the revolutionary intelligentsia (Vucinich 1988).

Tymiriazev had left the university and, because of his ill-health, did not teach but limited his meetings with students and colleagues to small gatherings in his Moscow flat. By the time Oparin graduated, he had an academic background that combined natural history, biochemistry, and plant physiology, a knowledge acquired within a research tradition strongly committed to integral approaches in the analysis of natural phenomena. He was not only familiar with nearly all the literature on evolution available in Russia but, perhaps even more important, with the Darwinian method of comparative analysis and historical interpretation of life features (Lazcano 1992). 


\section{A. Lazcano}

Like many of his fellow students and colleagues, Oparin was well acquainted with Haeckel's work, in which the transition of the nonliving to the first organisms was discussed but always under the assumption that the first forms of life had been autotrophic microbes. Analysis of Oparin's writings shows that throughout his entire life he remained faithful to the Haeckelian division of life into plants, animals and protists. However, from the very beginning it was impossible for him to reconcile his biochemical understanding of the sophistication of photosynthesis and the Darwinian credence in a gradual, slow evolution from the simple to the complex, with the suggestion that life had emerged already endowed with an autotrophic metabolism that included enzymes, chlorophyll and the ability to synthesize organic compounds from $\mathrm{CO}_{2}$ and water.

Because a heterotrophic anaerobe is metabolically simpler than an autotrophic one, Oparin argued, the former would necessarily have evolved first. Thus, based on the simplicity and ubiquity of fermentative reactions, he proposed that the first organisms must have been heterotrophic bacteria that could not make their own food but obtained organic material present in the primitive milieu. To buttress his intuition, Oparin needed to show that organic material could form in the absence of living beings. Two important pieces of evidence supported his claim that the first organisms were more likely to have been heterotrophic. First, hydrocarbons and other organic material were known to be present in meteorites, and perhaps even in comets. These facts had been known since the middle of the 19th century. Second, his proposal was sustained by the striking 19th century experimental synthesis of organic compounds discussed earlier, including the 1877 abiotic formation of long chain hydrocarbons reported by Mendeleyeev.

Careful reading of Oparin's 1924 book shows that, in contrast to common belief, at first he did not assume an anoxic primitive atmosphere. In his original scenario he argued that whereas some carbides, i.e., carbon-metal compounds, extruded from the young Earth's interior would react with water vapor leading to hydrocarbons, others would be oxidized to form aldehydes, alcohols, and ketones (such as acetone). These molecules would then react among themselves and with $\mathrm{NH}_{3}$ originating from the hydrolysis of nitrides (nitrogenmetals),

$$
\begin{aligned}
& \mathrm{Fe}_{\mathrm{m}} \mathrm{C}_{\mathrm{n}}+4 \mathrm{mH}_{2} \mathrm{O} \longrightarrow \mathrm{mFe}_{3} \mathrm{O}_{4}+\mathrm{C}_{3 \mathrm{n}} \mathrm{H}_{8 \mathrm{~m}} \\
& \mathrm{FeN}+3 \mathrm{H}_{2} \mathrm{O} \longrightarrow \mathrm{Fe}(\mathrm{OH})_{3}+\mathrm{NH}_{3}
\end{aligned}
$$

to form "very complicated compounds," as Oparin (1924) wrote, from which proteins and carbohydrates would form, that would rapidly form droplets of gel-like material ancestral to the first cells.

Similar proposals for a heterotrophic origin were also published in 1924 by the geochemist Charles Lipman and the microbiologist R.B. Harvey, although they were not as refined as Oparin's book. Quite significantly, Harvey argued that life had first evolved in a hot spring, where the high temperature would allow chemical reactions to proceed at a significant rate even if the first living beings were endowed with just a few enzymes. The most significant proposal, however, came from John B.S. Haldane, a versatile British biologist who became one of the founding fathers of neodarwinism. Haldane, like Oparin, argued that the origin of life had been preceded by the synthesis of organic compounds (Haldane, 1929). Based on experiments by the British chemist E.C.C. Baly, who claimed that he had synthesized amino acids (Baly 1924) and sugars by the UV irradiation of a solution of $\mathrm{CO}_{2}$ in water (Baly et al. 1927), Haldane suggested that the absence of oxygen in a $\mathrm{CO}_{2}$-rich primitive atmosphere had led to the synthesis of organic compounds and the formation of a "hot dilute soup." Haldane was also influenced by D'Herelle's discovery of phages, and suggested that viruses represented an intermediate step in the transition from the prebiotic soup to the first heterotrophic cells. Life may have remained, wrote Haldane (1929) "in the virus stage for many millions of years before a suitable assemblage of elementary units was brought together in the first cell." 
The Painful Maturation of the Heterotrophic Theory

Oparin belonged to a generation that was experiencing the liberal, high-bourgeois cultural and scientific circles of Saint Petersburg and Moscow formed by broad-minded scholars like Pavlov and Vernandsky. He was also encouraged to develop and support materialistic ideas by the secular atmosphere that followed the 1917 Bolschevik revolution. His 1924 book can be read as the work of a young, bold, and talented researcher with abundant enthusiasm and free of intellectual prejudices, who was able to look beyond the boundaries separating different scientific fields. In retrospect, it can be also considered the harbinger of his major work, a 1936 volume in Russian also called Origin of Life, whose English translation became available 2 years later (Oparin 1938).

The new volume was far more mature and profound in its philosophical and evolutionary analysis, as argued forcefully by Graham (1972), reflecting the changes in a society that was attempting to develop science, art and culture within the framework of dialectical materialism. In his second book Oparin (1938) not only abandoned his naïve and crude materialism, but also provided a thorough presentation and extensive analysis of the literature on the abiotic synthesis of organic material. His original proposal was revised, leading to the assumption of a highly reducing primitive mileu in which iron carbides of geological origin would react with steam to form hydrocarbons. Their oxidation would yield alcohols, ketones, aldehydes, etc., that would then react with ammonia to form amines, amides and ammonium salts. The resulting proteinlike compounds and other molecules would form a dilute solution, where they would aggregate to form colloidal systems from which the first heteretrophic microbes evolved (Oparin 1938).

Oparin further argued that coacervate drops represented the optimal mechanism to concentrate organic material on the primitive Earth. Coacervates are charged, microscopic organic colloidal droplets that can concentrate organic materials existing in the medium.
Historical Development of Origins Research

Because coacervates form spontaneously when two solutions of macromolecules with opposite charges are mixed, it is quite possible that they were present in the prebiotic milieu. However, they lack the lipid bilayers, present in all cells that retain organic matter in high concentrations inside a self-constructed boundary. Therefore, coacervates are no longer considered as potentially ancestral to life itself. Coacervates were the favorite model for a considerable time after Oparin's views became widely known, because they were perceived as mimicking the surmised properties of precellular systems, but the development of a more sophisticated understanding of cells led to their dismissal as constituting any step toward the origins of life (Deamer 1977).

A highly reducing atmosphere would be, for Oparin, a mixture of $\mathrm{CH}_{4}, \mathrm{NH}_{3}$, and $\mathrm{H}_{2} \mathrm{O}$ with or without added $\mathrm{H}_{2}$. The atmosphere of Jupiter contains these chemical species, with $\mathrm{H}_{2}$ in large excess over $\mathrm{CH}_{4}$. Oparin's proposal of a primordial reducing atmosphere was a brilliant inference from the then fledging knowledge of solar atomic abundances and planetary atmospheres, as well as from Vernadsky's idea that the early Earth would be anoxic in the absence of life because molecular oxygen is a product of photosynthesis. As summarized elsewhere (Miller et al. 1997) the benchmark contributions of Oparin's 1938 book include not only the hypothesis that heterotrophs and anaerobic fermentation were primordial and the proposal of a reducing atmosphere for the prebiotic synthesis and accumulation of organic compounds, but also the idea that the association of molecules in precellular systems was a necessary prerequisite for their evolution (Miller et al. 1997). Oparin was aware that the significance of coacervates as laboratory models of such polymolecular systems had been diminished by more recent developments. When he visited Mexico to receive an honorary degree that my university had granted him, Celia Ramírez and I gave him a copy of Light Transducing Membranes, which David W. Deamer (1977) had edited two years before. "If I had the chance to start all over again," he remarked, "I would work on liposomes rather than on coacervates as models of precellular systems." 
A. Lazcano

As Farley (1977) wrote, Oparin's 1938 book may be the most significant work ever published on the origin of life. It is true that many of his original ideas have been superseded. However, over the years it has become clear that the open character of his theory of chemical evolution has allowed the incorporation of new discoveries and the development of more accurate descriptions of possible primitive scenarios without destroying its overall structure and premises. The heterotrophic theory has not been belittled, for instance, but magnified by the recognition of the key role that genetic material must have placed in the origin of life. Perhaps the most important scientific achievements of Oparin may be his insistence that life is the evolutionary outcome of a process and not of a single event, as well as the methodological breakthrough that transformed the study of the origin of life from a purely speculative problem into a workable multidisciplinary research program.

The Miller-Urey Experiment: The Birth of Prebiotic Chemistry

The English translation of Oparin's second book caught the attention of biologists such as Norman Horowitz and Cornelius van Niel, but during the next 10 years, while World War II raged, little progress was made in research on the origins of life. Driven by his interest in evolutionary biology, Melvin Calvin attempted to simulate the synthesis of organic compounds under primitive Earth conditions using the high-energy radiation sources available at the Lawrence Berkeley Laboratory. $\mathrm{He}$ and his group had limited success: The irradiation of $\mathrm{CO}_{2}$ solutions with the Crocker Laboratory's 60-inch cyclotron led only to formic acid, albeit in fairly high yields (Garrison et al., 1951).

By the time Calvin and his colleagues published their results, Harold C. Urey had already moved from Columbia to the University of Chicago, where he started to work on cosmochemistry. He rapidly became convinced the Earth's earliest atmosphere was highly reducing, with $\mathrm{CH}_{4}$ and $\mathrm{NH}_{3}$ instead of $\mathrm{CO}_{2}$ and $\mathrm{N}_{2}$. In 1951 Urey gave a seminar dealing with the origin of the Solar System, and argued that the reducing conditions on the early Earth may have been important to the emergence of life. As he wrote in his 1952 book The Planets: Their origin and development, "if half the present surface carbon existed as soluble organic compounds and only 10 per cent of the water of the present oceans existed on the surface of the primitive earth, the primitive oceans would have been approximately a 10 per cent solution of organic compounds. This would provide a very favorable situation for the origin of life" (Urey 1952).

Stanley L. Miller, who had arrived to Chicago in the spring of 1951 after graduating from the University of California, Berkeley, attended Urey's lecture, who like Oparin suggested that it would be interesting to simulate the proposed reducing conditions of the primitive Earth to test the feasibility of organic compound synthesis. "Urey's point immediately seemed valid to me," wrote Miller many years afterward. "After this seminar someone pointed out to Urey that in his book Oparin had discussed the origin of life and the possibility of synthesis of organic compounds in a reducing atmosphere. Urey's discussion of the reducing atmosphere was more thorough and convincing than Oparin's; but it is still surprising that no one had by then performed an experiment based on Oparin's ideas" (Miller 1974).

Almost a year and a half after Urey's lecture, Miller approached Urey about the possibility of doing a prebiotic synthesis experiment using a reducing gas mixture. After overcoming Urey's initial resistance, he designed three apparatuses meant to simulate the ocean-atmosphere system on the primitive Earth by investigating the action of electric discharges acting for a week on a mixture of $\mathrm{CH}_{4}, \mathrm{NH}_{3}, \mathrm{H}_{2}$, and $\mathrm{H}_{2} \mathrm{O}$; racemic mixtures of several protein amino acids were produced, as well as hydroxy acids, urea, and other organic molecules (Miller 1953, 1955; Johnson et al. 2008).

Miller achieved his results by means of an apparatus in which he could simulate the interaction between an atmosphere and an ocean. To activate the reaction, Miller used an electrical spark, which was considered to be a significant energy source on the early Earth in the 
form of lightning and coronal discharges. The apparatus was filled with various mixtures of methane, ammonia, and hydrogen as well as water, the latter being heated to boiling during the experiment. A spark discharge between the tungsten electrodes was produced by a high frequency Tesla coil with a voltage of 60,000 V. The reaction time was usually a week or so and the maximum pressure 1.5 bars. With this relatively simple experimental setup, Miller (1953) was able to transform almost $50 \%$ of the original carbon (in the form of methane) into organic compounds. Although most of the synthesized organic material was an insoluble tarlike solid, he was able to isolate amino acids and other simple organic compounds from the reaction mixture. Glycine, the simplest amino acid, was produced in $2 \%$ yield (based on the original amount of methane carbon), whereas alanine, the simplest amino acid with a chiral center, showed a yield of $1 \%$. Miller was able to show that the alanine was a racemic mixture (equal amounts of D- and L-alanine). This provided convincing evidence that the amino acids were produced in the experiment and were not biological contaminants somehow introduced into the apparatus.

\section{DNA versus Coacervates? The Reshaping of an Old Debate}

The Miller paper (1953) was published only a few weeks after Watson and Crick's (1953) classic article revealed their double helix model for the structure of DNA. With few exceptions, like Sidney W. Fox's work on thermal polypeptides (cf. Fox and Dose 1977), modern attempts to understand the origin of life have been shaped by our burgeoning knowledge of DNA replication and protein biosynthesis. Prebiotic chemistry and molecular biology began to converge, albeit slowly, when Oró (1960) showed the remarkable ease with which adenine could be produced through the oligomerization of $\mathrm{HCN}$.

Hermann J. Muller quickly used the developments in molecular genetics and the success in prebiotic syntheses to update his gene-first proposal by arguing that what had emerged in the primitive oceans had been, in fact, a primordial DNA molecule : “... it is to be expected that at last, just before the appearance of life, the very ocean had become, in Haldane's (1929, 1954) vivid phraseology, a gigantic bowl of soup," wrote Muller, and added "drop into this a nucleotide chain and it should eventually breed!" (Muller 1961). A few years later he would state that ". . .life as we know it, if stripped of all its superstructures, lies in the three faculties possessed by the gene material. These may be defined as, firstly, the self-specification, after its own pattern, of new material produced by it or under its guidance; secondly, of performing this operation even when it itself has undergone a great succession of permanent pattern changes which, taken in their totality, can be of a practically unlimited diversity; thirdly, of, through these changes, significantly and (for different cases) diversely affecting other materials and, therewith, its own success in genetic survival." Muller added that "the gene material alone, of all natural materials, possesses these faculties, and it is therefore legitimate to call it living material, the present-day representative of the first life" (Muller 1966). In other words, for Muller (and many others) the essence of life lies in the combination of autocatalysis, heterocatalysis, and mutability, i.e., evolvability.

Muller's proposal was brilliantly reductionist, and was soon contested by Oparin and others in a now largely forgotten debate. Although Muller (1947) had once expressed sympathy to Oparin's idea, they soon became engaged in an entangled debate in which science, philosophy, and politics mixed in an excruciating discussion that was shaped in part by the Cold War atmosphere (Lazcano 1992, 1995; Fry 2002). In sharp contrast with Muller's ideas, Oparin (1938) had argued that the essence of life was metabolic flow. For Oparin, life is "a special form of the motion of matter," always in flow, which included enzymatically based assimilation, growth, and reproduction, but not nucleic acids, whose genetic role was not even suspected during the 1930s. Biological inheritance was assumed by Oparin to be the outcome of growth and division of the coacervate drops he had suggested as models of precellular systems, a view that 


\section{A. Lazcano}

led Muller (1966) to state that "the Russian Oparin has since the early 1930s espoused this view and has followed the official Communist Party line by giving the specific genetic material a back seat."

Oparin and Muller came from different scientific backgrounds and almost opposite intellectual traditions. Their common interest in the origin of life did nothing to assuage their opposing views and their ideological clashes. Oparin was a convinced evolutionist, and, like many of his contemporaries, his original genetics were pre-Mendelian. Oparin's Darwinism had been nurtured by Tymiriazev, who had famously identified in 1912, many years before the Lysenko affair, Mendelians and mutationists as the opponents to be defeated in the war against anti-Darwinism (Vucinich 1988). For Muller, who remained bitterly disillusioned by Stalin's regime and Lysenko's tragic affair, life could be so well-defined that the exact point at which it started could be established with the sudden appearance of the first DNA molecule. Oparin, on the other hand, refused to admit that life could arise all at once by a spontaneous generation, and argued that it was the outcome of a slow, stepwise evolutionary developmental process.

Oparin's refusal to assume that nucleic acids had played a unique role in the origin of life resulted not only from his unwillingness to assume that life can be reduced to a single compound such as the "living DNA molecule" advocated by Muller and others, but also within the framework of Cold War politics, his complex relationship with Lysenko, and his long association with the Soviet establishment. As shown by his extensive work with RNA-containing coacervates (Oparin and Yevreinova, 1947; Oparin and Serebroskaya, 1963; Oparin et al. 1961, 1963, 1964) and his complete acceptance, based on the suggestions of Belozerskii (1959), Brachet (1959), and others, that RNA could have preceded DNA as genetic material, Oparin (1961) eventually acknowledged the role of nucleic acids in the origin of life and assumed, until the very end, that protein synthesis was the evolutionary outcome of the interaction of primordial polypeptides and polynucleotides within the boundaries of precellular systems (Oparin 1972).

\section{Paving the Road to the RNA World}

The launching of the Sputnik in 1957 signaled not only the start of space exploration but also a new epoch in the study of the origins of life, which acquired a novel perspective, as shown by the publication of Life in the Universe, a book by Oparin and Fesenkov (1961). The first chapter, written by Oparin, examined the conditions under which life was assumed to have originated on Earth, and the rest of the book by Vasily Fesenkov, an astronomer with considerable following in the USSR. The premise that life appeared throughout the Universe whenever the conditions for its appearance were present set the tone the book, and reflected optimistic views regarding the possibility of inhabited planets shared by many astronomers both in the Soviet Union and in Western countries. By then, the development of space programs and agencies had started to play a key role not only in transforming the issue of extraterrestrial life into a legitimate scientific question, but also to shape the study of origin and early evolution of life in new ways (Dick 1998; Wolfe 2002; Strick 2004).

If the onset of the so-called Space Age (which led to substantial funding from NASA to the origins-of-life community) set the emergence of living systems within a cosmic context, the work of Elso S. Barghoorn and his students and associates pushed the microbial fossil record back in time to the early Precambrian (Cloud 1983). Although it seems that life appeared as soon as environmental conditions permitted, identification of the oldest paleontological traces of life remains a contentious issue. Although it is not possible to assign a precise chronology to the origin and earliest evolution of cells, the recognition that life is a very ancient phenomenon runs parallel to the limits imposed by a geological record that becomes increasingly blurred as we go back in time (Schopf 1999; Knoll 2003).

Direct information is lacking not only on the composition of the terrestrial atmosphere 
during the period of the origin of life, but also on the temperature, ocean $\mathrm{pH}$ values, and other general and local environmental conditions which may or may not have been important for the emergence of living systems. However, the lack of detailed understanding of the conditions of the primitive environment did not stop prebiotic chemists from attempting the synthesis of a wide number of compounds of biochemical significance under highly reducing conditions but with few other environmental constraints. The robustness of this type of chemistry is supported by the occurrence of most of these biochemical molecules in the Murchison meteorite, reinforcing, but not proving, the idea that comparable compounds were present in the primitive Earth (Ehrenfreund et al. 2002).

From the late 1960s onward, however, it became clear that our understanding of the origin of life was troubled by two major issues: The possibility that the young Earth had been endowed with a highly reducing atmosphere was viewed with considerable skepticism by most planetary scientists, whose preference for a $\mathrm{CO}_{2}$-rich atmosphere weakened the assumption that the primitive soup had formed by the accumulation of organic compounds synthesized under highly reducing conditions. Secondly, the emergence of nucleic acid-directed protein synthesis, which is recognized as a central feature of all extant life, appeared to be an insurmountable problem. At the time, few molecular biologists were inclined to evolutionary explanations and many, like Muller, relied on chance events to understand the basic molecular traits of cells. As the influential French biologist Jacques Monod wrote in his 1970 book Chance and Necessity, "... it might be thought that the discovery of the universal mechanisms basic to the essential properties of living beings would have helped solve the problem of life's origins. As it turns out, these discoveries, by almost entirely transforming the question, have shown it to be even more difficult than it formerly appeared" (Monod 1971). Monod's attitude had far reaching consequences; as summarized by Fry (2002), it would eventually lead the philosopher Karl Popper (1974) and his followers to argue that the emergence of life is "an impenetrable barrier to science and a residue to all attempts to reduce biology to chemistry and physics."

A possible solution to the problem posed by the lack of understanding of the relationship between nucleic acids and proteins was suggested by Carl Woese (1967), Leslie Orgel (1968), and Francis Crick (1968), who independently proposed the idea that the first living entities were based on RNA as both the genetic material and as catalyst. Surprisingly, these pioneering proposals of an RNA world received little attention. The relationship between evolutionary issues and molecular biology was slow to develop, and during several decades was embittered by frequent clashes during which evolutionary analysis was frequently dismissed as little more than useless speculation.

This skeptical attitude changed with the awareness that genes and proteins are rich historical documents from which a wealth of evolutionary information can be retrieved (Zuckerkandl and Pauling 1965). A major achievement of this approach was the use of small subunit ribosomal RNA as a phylogenetic marker, which led Carl Woese and his associates to the construction of a trifurcated, unrooted tree in which all known organisms can be grouped in one of three major cell lineages, i.e., eubacteria, archaeabacteria, and the eukaryotic nucleocytoplasm, all of which share a common ancestry (Woese and Fox 1977). The variations of traits common to extant species can be explained as the outcome of divergent processes from an ancestral life form that existed before their separation of the three major biological domains, i.e., the last common ancestor. Although no evolutionary intermediate stages or ancient simplified versions of the basic biological processes have been discovered in contemporary organisms, the differences in the structure and mechanisms of gene expression and replication among the three lineages have provided insights on the stepwise evolution of the replication and translational apparatus, including some late steps in the development of the genetic code. All of a sudden, it deemed possible to distinguish the origin of life problem from a whole series of other 


\section{A. Lazcano}

issues, often confused, that belong to the domain of the evolution of microbial life.

\section{RECENT RESULTS}

So Far from the Origin of Life, so Close to the RNA World

It is difficult to see how inferences based on universal phylogenies can be extended beyond a threshold that corresponds to a period of cellular evolution in which protein biosynthesis was already in operation, i.e., an RNA/protein world. Older stages are not yet amenable to molecular phylogenetic analysis (Becerra et al. 2007). A cladistic approach to the origin of life itself is not feasible, because all possible intermediates that may have once existed have long since vanished, and the temptation to do otherwise is best resisted. The most basic questions pertaining to the origin of life relate to much simpler entities predating by a long (but not necessarily slow) series of evolutionary events the oldest branches in universal phylogenetic trees.

Nevertheless, the examination of the prokaryotic branches of unrooted rRNA trees had already suggested that the ancestors of both Bacteria and Archaea were extreme thermophiles growing optimally at temperatures in the range of $90^{\circ} \mathrm{C}$ or above (Achenbach-Richter et al. 1987). Rooted universal phylogenies appeared to confirm this possibility, because heat-loving prokaryotes occupied short branches in the basal portion of molecular cladograms (Stetter 1994). Attempts to correlate the antiquity of hyperthermophiles with extreme environments such as those found today in deep-sea vents (Holm 1992) or in other sites in which mineral surfaces may have fueled the appearance of primordial chemoautolithotrophic life forms (Wächtershäuser 1988, 1992) became almost unavoidable.

Wächtershäuser's explicit adherence to Karl Popper's philosophical stand (Popper 1959) played a major role in his idea that life began with the appearance of an autocatalytic twodimensional autochemolithotrophic metabolic system based on the formation of pyrite. His insightful prediction that ferrous sulfide in the presence of hydrogen sulfide $\left(\mathrm{H}_{2} \mathrm{~S}\right)$ is an efficient reducing agent should not be understated. Pyrite formation can produce molecular hydrogen, promote the formation of ammonia from nitrogen nitrogen, and can reduce a few organic molecules under mild conditions. However, compared with the surprising variety of biochemical compounds that are readily synthesized in one-pot Miller-Urey type simulations, the suite of molecules produced under the conditions suggested by Wächtershäuser is quite limited.

Based on the hypothesis that core metabolic processes have not changed since the emergence of life, Morowitz (1992) has argued that intermediary metabolism recapitulates prebiotic chemistry. He maintains that the basic traits of metabolism could only evolve after the closure of an amphiphilic bilayer membrane into a vesicle, that is, that the appearance of membranes represents the discrete transition from nonlife to life. According to his hypothesis, reverse Krebs cycle-dependent life appeared with "minimal protocells" formed by bilayer vesicles made up of small amphiphiles and endowed with pigments capable of absorbing radiant energy stored as a chemiosmotic proton gradient across the membrane.

These and other explanations of the origin of life are based on the idea that the emergence of autocatalytic "metabolic" cycles in the primitive Earth was an essential prerequisite for the appearance of genetic systems. According to this approach, life can be considered an emergent interactive system endowed with dynamic properties that exist in a state close to chaotic behavior. Some of these proposals reflect a (healthy) reaction against molecular biology reductionism, as well as the adherence to allencompassing views based on complexity theories and self-assembly phenomena that are quite popular among physical scientists. In fact, the background of current metabolism-based explanations of the origin of life lies not in Oparin's proposals, but in the attempts to extrapolate to biology the deeply rooted tendency in physical sciences to search for all encompassing laws that can be part of grand theory which explain many, if not all, complex systems. 
The many examples of self-organizing physical systems that lead to highly ordered structures show that, in addition to natural selection, other mechanisms of ordered complexity can come into play. Self-assembly is not unique to biology, and may indeed be found in a wide variety of systems, including cellular automata, the complex flow patterns of many different fluids, in cyclic chemical phenomena (such as the Belousov-Zhabotinsky reaction) and, quite significantly, in the self-assembly of amphiphilic lipid-like molecules in bilayers, micelles, and liposomes (cf. Lazcano 2009). There are indeed some common features among these systems, and it has been claimed that they follow general principles that are in fact equivalent to universal laws of nature (Kauffman 1993). Perhaps this is true. The problem is that such all-encompassing principles, if they exist at all, have so far remained undiscovered (Farmer 2005).

As discussed elsewhere, the experimental evidence that has been recently used to argue in favor of the metabolism-first theory is equally consistent with a genetic-first description of life (Lazcano 2009). What the metabolic-first approaches require is the confirmation that metabolic (or protometabolic) routes can replicate and evolve. So far, there are no indications that this is the case: As summarized by Leslie Orgel in a posthumous paper, theories that advocate the emergence of complex, selforganized biochemical cycles in the absence of genetic material are hindered not only by the lack of empirical evidence, but also by a number of unrealistic assumptions about the properties of minerals and other catalysts required to spontaneously organize such sets of autocatalytic chemical reactions (Orgel 2008).

\section{CHALLENGES AND FUTURE DIRECTIONS}

The remarkable coincidence between the monomeric constituents of living organisms and those synthesized in laboratory simulations of the prebiotic environment appears to be too striking to be fortuitous. Although we are far from understanding how life appeared, the available experimental evidence strongly suggest that the prebiotic environment was already endowed with a wide range of monomers of biochemical significance, many organic and inorganic catalysts, purines and pyrimidines, i.e., the potential for template-directed polymerization reaction, and membrane-forming compounds. Nevertheless, at present the hiatus between the primitive soup and the RNA world is discouragingly enormous.

There are many definitions of the RNA World. However, the discovery of ribozymes does not imply that wriggling autocatalytic nucleic acid molecules ready to be used as primordial genes were floating in the primitive oceans, or that the RNA world emerged completely assembled from simple precursors present in the prebiotic broth. Although it is true that genetic-first proposals do not require enclosure within compartments, the emergence of life may be best understood in terms of the dynamics and evolution of sets of chemical replicating entities. Whether such entities were enclosed within membranes is not yet clear, but given the prebiotic availability of amphiphilic compounds this may have well been the case (Deamer 2002). Indeed, the evidence supporting the presence of lipidic molecules in the prebiotic environment and their natural ability to self-organize into vesicular compartments underlines the significance of theoretical models of simple cells involving an evolving ribozymic RNA polymerase (Szostak et al. 2001; Deamer and Dworkin 2005) and increasingly sophisticated laboratory models of precellular systems (Mansy et al. 2008).

For obvious methodological reasons, experimental simulations of prebiotic events have concentrated on the empirical analysis of single variables. The study of more specific conditions, including the laboratory simulation of localized environments such as volcanic islands, tidal zones and microenviroments, including liposomes, clays and mineral surfaces, and volcanic ponds, which could have been prevalent in the primitive environment, are likely to yield promising results. It is reasonable to assume that the association and interplay of different biochemical monomers and oligomers in more complex experimental settings would lead to physicochemical properties not 


\section{A. Lazcano}

shown by their isolated components (Deamer et al. 2002). This is not purely speculative; that interactions between liposomes and different water-soluble polypeptides lead to major changes in the morphology and permeability of liposomes of phosphatidyl-L-serine, and to a transition of poly-L-lysine from a random coil into an $\alpha$-helix that shows hydrophobic bonding with the lipidic phase, has been documented in the laboratory (Hammes and Schullery 1970).

Additional examples include experimental models of compartmentalized catalytic RNA (Mansy et al. 2008), which, although they do not necessarily correspond to particular stages in the origin of life, nonetheless illustrate how individual components of a system dynamically interact and lead to unexpected new properties. This approach, which falls within the venerable tradition of synthetic biology (Peretó and Catalá 2007), complements the attempts to work backward to reduce extant cell genomes and achieve the laboratory synthesis of minimal life forms.

There are inevitable gaps in the story, but reports on the death of the heterotrophic theory have been greatly exaggerated. The remarkable coincidence between the surprising variety of biochemical constituents that can be readily synthesized in experiments simulating the prebiotic environment and those found in some carbon-rich meteorites appears to be too striking to be fortuitous. The Earth's primitive atmosphere may have not been as strongly reducing as assumed by the early proponents of the prebiotic broth, but there is experimental evidence showing that amino acids can be synthesized in a $\mathrm{CO}_{2}$-rich model atmosphere (Cleaves et al. 2008). It is true that the classical recipe for cooking a primitive soup needs to be updated to acknowledge, in an eclectic fashion, the contribution of extraterrestrial organic compounds, the role of catalytic minerals like pyrite, and the synthesis of organic molecules in hydrothermal vents, however limited it may have been, but this poses no threat to the idea of chemical evolution as a prerequisite to an heterotrophic origin of life.

We will never know how life first appeared. However, the study of the appearance of life is a mature, well-established field of scientific inquiry. As in other areas of evolutionary biology, answers to questions on the origin and nature of the first life forms can only be regarded as inquiring and explanatory rather than definitive and conclusive. This does not imply that all origin-of-life theories and explanations can be dismissed as pure speculation, but rather that the issue should be addressed conjecturally, in an attempt to construct not a mere chronology but a coherent historical narrative by weaving together a large number of miscellaneous observational findings and experimental results. It is probably useful to remember the line from Goethe's Faust that Oparin included in his 1924 book, "My worthy friend, gray is all theory, and green alone is life's golden tree."

\section{ACKNOWLEDGMENTS}

This article was completed during a sabbatical leave in which I enjoyed the hospitality of Professor Jeffrey L. Bada and his associates at the Scripps Institution of Oceanography, University of California San Diego. Support from a UC Mexus-CONACYT Fellowship is gratefully acknowledged.

\section{REFERENCES}

Achenbach-Richter L, Gupta R, Stetter KO, Woese CR. 1987. Were the original eubacteria thermophiles? System Appl Microbiol 9: 34-39.

Bada JL, Lazcano A. 2003. Prebiotic soup: Revisiting the Miller experiment. Science 300: 745-746.

Baly ECC. 1924. Photosynthesis. Industrial Eng Chem 16: 1016-1018.

Baly ECC, Davies JB, Johnson MR, Shanassy H. 1927. The photosynthesis of naturally occurring compounds. 1. The action of ultraviolet light on carbonic acid. Proc Roy Soc London A 116: 197-208.

Becerra A, Delaye L, Islas A, Lazcano A. 2007. Very early stages of biological evolution related to the nature of the last common ancestor of the three major cell domains. Annu Rev Ecol Evol Syst 38: 361-379.

Belozerskii AN. 1959. On the species specificity of the nucleic acids of bacteria. In A.I. Oparin, A.G. Pasynskii, A.E. Braunshtein, T.E. Pavloskaya (Eds.), The Origin of Life on Herat Pergamon Press, New York, pp. 322-321.

Brachet J. 1959. Les acides nucléiques et l'origine des protéines. In A.I. Oparin, A.G. Pasynskii, A.E. Braunshtein, 
T.E. Pavloskaya (Eds.), The Origin of Life on Earth New York: Pergamon Press. pp. 361-367.

Carlson EA. 1981. Genes, radiation, and society: The life and work of H J Muller Ithaca: Cornell University Press.

Cleaves JH, Chalmers JH, Lazcano A, Miller SL, Bada JL. 2008. Prebiotic organic synthesis in neutral planetary atmospheres. Origins Life Evol Biosph 38: 105-155.

Cloud P. 1983. Early biogeologic history: The emergence of a paradigm. In J.W. Schopf (ed), Earth's earliest biosphere: Its origin and evolution Princeton: Princeton University Press pp. 14-31.

Crick FHC. 1968. The origin of the genetic code. J Mol Biol 39: 367-380.

Deamer DW. 1977. (ed.) Light transducing membranes New York: Academic Press.

Deamer DW, Dworkin JP. 2005. Chemistry and physics of primtive membranes. In P. Walde (ed.), Prebiotic chemistry: From simple amphiphiles to protocell models pp. 1-27. Berlin: Springer.

Deamer DW, Dworkin JP, Sanford SA, Bernstein MP, Allamandola LJ. 2002. The first cell membranes. Astrobiology 2: 371-382.

Dick SJ. 1998. Life on other worlds Cambridge: Cambridge University Press.

D'Herelle F. 1926. The Bacteriophage and its behaviour Baltimore: William and Wilkins.

Ehrenfreund P, Irvine W, Becker L, Blank J, Brucato J, Colangeli L, Derenne S, Despois D, Dutrey A, Fraaije H, Lazcano A, Owen T, Robert F. 2002. Astrophysical and astrochemical insights into the origin of life. Reports Prog Phys 65: 1427-1487.

Farley J. 1977. The spontaneous generation controversy from Descartes to Oparin Baltimore and London: Johns Hopkins University Press.

Farmer DJ. 2005. Cool is not enough. Nature 436: 627-628.

Fox SW, Dose K. 1977. Molecular evolution and the origin of life New York: Marcel Dekker Inc.

Fry I. 2002. The emergence of life on earth New Brunswick: Rutgers University Press.

Fry I. 2006. The origins of research into the origins of life. Endeavour 30: 24-28.

Garrison WM, Morrison DC, Hamilton JG, Benson A, Calvin M. 1951. Reduction of carbon dioxide in aqueous solutions by ionizing radiation. Science 114: 416 .

Graham LR. 1972. Science and philosophy in the Soviet Union New York :Alfred A. Knopf.

Haeckel E. 1862. Die Radiolarien (Rhizopoda Radiaria) Eine Monographie Berlin: Druck und Verlag Von Georg Reimer.

Haldane JBS. 1929. The origin of life. Rationalist Annual 148: $3-10$.

Haldane JBS. 1954. The origins of life. New Biol 16: 12-27.

Hammes GG, Schullery SE. 1970. Structure of molecular aggregates. II. Construction of model membranes from phospholipids and polypeptides. Biochemistry 9: 2555-2558.

Herrera AL. 1902. Note sur l'imitation du protoplasme. Bull Soc Zoo France 26: 144.

Herrera AL. 1942. A new theory on the origin and nature of life. Science 96: 14.
Historical Development of Origins Research

Holm N.G., ed. 1992. Marine hydrothermal systems and the origin of life Dordrecht: Klüwer Academic Publ.

Johnson AP, Cleaves HJ, Dworkin JP, Glavin DP, Lazcano A, Bada JL. 2008. The Miller volcanic spark discharge experiment. Science 322: 404.

Kauffman SA. 1993. The Origins of Order: Self organization and selection in evolution New York: Oxford University Press.

Kamminga H. 1982. Life from space-a history of panspermia. Vistas in Astronomy 26: 67-86

Knoll AH. 2003. Life on a young planet: The first three billion years of evolution on Earth Princeton: Princeton University Press.

Lazcano A. 1992. La Chispa de la Vida: Alexander I. Oparin Editorial Pangea/CONACULTA, México, D.F. (in Spanish).

Lazcano A. 1995. Aleksandr I. Oparin, the man and his theory. in B.F. Poglazov, B.I. Kurganov, M.S. Kritsky (eds), Frontiers in Physicochemical Biology and Biochemical Evolution Bach Institute of Biochemistry and ANKO, Moscow, p. 49-56.

Lazcano A. 2009. Which way to life? Origins Life Evol Biosph (in press).

Leicester HM. 1974. Development of Biochemical Concepts from Ancient to Modern Times Cambridge: Harvard University Press.

Mansy SS, Schrum JP, Krishnamurthy M, Tobé S, Treco DA, Szostak JJW. 2008. Template-directed synthesis of a genetic polymer in a model protocell. Nature 454: $122-125$.

Miller SL. 1953. A production of amino acids under possible primitive Earth conditions. Science 117: 528.

Miller SL. 1955. Production of some organic compounds under possible primitive Earth conditions. J Am Chem Soc 77: 2351-2361.

Miller SL. 1974. The first laboratory synthesis of organic compounds under primitive conditions. In: J. Neyman (ed) The Heritage of Copernicus: Theories "more pleasing to the mind" pp 228-24. Cambridge: MIT Press.

Miller SL, Schopf JW, Lazcano A. 1997. Oparin's "Origin of Life": Sixty years later. J Mol Evol 44: 351-353.

Morowitz HJ. 1992. Beginnings of Cellular Life: Metabolism Recapitulates Biogenesis Binghamton: Yale University Press.

Monod J. 1971. Chance and Necessity Glasgow: Fontana Books.

Muller HJ. 1922. Variation due to change in the individual gene. The American Naturalist, 56: 32-50.

Muller HJ. 1926. The gene as the basis of life. Proceedings of the 1st International Congress of Plant Sciences, Ithaca, p. 897-921.

Muller HJ. 1947. The gene. Proc Royal Soc B134: 1-37.

Muller HJ. 1961. Genetic nucleic acid: Key material in the origin of life. Persp Biol Med 5: 1-23.

Muller HJ. 1966. The gene material as the initiator and the organizing basis of life. Am Naturalist 100: 493-502.

Oparin AI. 1924. Proiskhozhedenie Zhizni Mosckovskii Rabochii, Moscow,. Reprinted and translated in J. D. Bernal (1967) The Origin of Life London: Weidenfeld and Nicolson. 


\section{A. Lazcano}

Oparin AI. 1938. The Origin of Life New York: McMillan.

Oparin AI. 1961. Life: Its nature, origin, and development New York: Academic Press.

Oparin AI. 1972. The appearance of life in the Universe. In C. Ponnamperuma (Ed.), Exobiology pp 1-15 Ámsterdam: North-Holland.

Oparin AI, Fesenkov V. 1961. Life in the Universe. New York: Twayne Publishers.

Oparin AI, Serebroskaya KB. 1963. Formation of coacervates drops during the synthesis of polyadenylic acid by polynucleotide phosphorylase. Dokl Akad Nauk SSSR 148: 943-947 (in Russian).

Oparin AI, Yevreinova TN. 1947. The effect of nucleic acid on thermostability of proteins. Dokl Akad Nauk SSSR 58: 253-259 (in Russian).

Oparin AI, Serebroskaya KB, Auerman TL. 1961. Synthesizing effect of polynucleotide phosphorylase of Micrococcus lyzodeikticus in solution and in coacervate systems. Dokl Akad Nauk SSSR 126: 499-504 (in Russian).

Oparin AI, Serebroskaya KB, Pantskhava SN, Vasil'yeva NV. 1963. Enzymatic synthesis of polyadenylic acid in coacervate drops. Biokhimiya 28: 671-673 (in Russian).

Oparin AI, Serebroskaya KB, Vasil'yeva NV, Balayevskaya TO. 1964. The formation of coacervates from polypeptides and polynucleotides. Dokl Akad Nauk SSSR 154: 407-412 (in Russian).

Orgel LE. 1968. Evolution of the genetic apparatus. $J$ Mol Biol 38: 381-392.

Orgel LE. 2008. The implausibility of metabolic cycles in the primitive Earth. PLoS Biol 6: e18.

Oró J. 1960. Synthesis of adenine from ammonium cyanide. Biochem Biophys Res Comm 2: 407-412.

Oró J. 1961. Comets and the formation of biochemical compounds on the primitive earth. Nature 190, 442-443.

Peretó J, Catalá J. 2007. The renaissance of synthetic biology. Biological Theory 2: 128-130.

Peretó J, Bada JE, Lazcano A. 2009. Charles Darwin and the origin of life. Origins Life Evol Biosph 39: 395-406.

Perezgasga L, Silva E, Lazcano A, Negrón-Mendoza A. 2003. Herrera's sulfocyanic theory on the origin of life: A critical reappraisal. Int Jour Astrobiol 2: 1-6.

Pontecorvo G. 1982. Who was H. J. Muller (1890-1967)? Nature 298: 203-204.

Popper K. 1959. The logic of scientific discovery. New York: Basic Books.

Popper K. 1974. Reduction and the incompleteness of science. In F. Ayala, T. Dobzhanzky (eds), Studies in the Philosophy of Biology University of California Press, Berkeley, pp 251-267.
Ravin AW. 1977. The gene as catalysts; the gene as organism. W. Coleman, C. Limoges (eds) Studies in the History of Biology 1: 1-45.

Schopf JW. 1999. The Cradle of Life: The discovery of Earth's earliest fossils. Princeton: Princeton University Press.

Stetter KO. 1994. The lesson of archaebacteria. In S. Bengtson (ed), Early Life on Earth: Nobel Symposium No 84 Columbia University Press, New York 114-122.

Strick JE. 2004. Creating a cosmic discipline: The crystallization and consolidation of exobiology, 1957-1973. Jour History Biol 37: 131-180.

Strick JE. 2009. Darwin and the origin of life: Public versus private science. Endeavour (in press).

Summers WC. 1999. Felix d'Herelle and the origins of molecular biology New Haven: Yale University Press.

Szostak JW, Bartel DP, Luisi PL. 2001. Synthesizing life. Nature 409:387-390.

Troland LT. 1914. The chemical origin and regulation of life. The Monist 22: 92-133.

Troland LT. 1916. The enzyme theory of life. Cleveland Me Jour 15: 377-385.

Troland LT. 1917. Biological enigmas and the theory of enzyme action. Am Naturalist 51: 321-350.

Urey HC. 1951. On the early chemical history of the Earth and the origin of life. Proc Natl Acad Sci USA 38: 351-363.

Urey HC. 1952. The planets: their origin and development Chicago: University of Chicago Press.

Vucinich A. 1988. Darwin in Russian Thought Berkeley: University of California Press.

Wächtershäuser G. 1988. Before enzymes and templates, a theory of surface metabolism. Microbiol Rev 52: 452-84.

Wächtershäuser G. 1992. Groundwork for an evolutionary biochemistry: The iron-sulphur world. Prog Biophys Molec Biol 58: 85-201.

Watson JD, Crick FHC. 1953. Molecular structure of nucleic acids. Nature 171: 737.

Woese CR. 1967. The Genetic Code: the molecular basis for gene expression. New York: Harper and Row.

Woese CR, Fox GE. 1977. The concept of cellular evolution. J Mol Evol 10:1-6.

Wolfe A. 2002. Germs in space: American life scientists, space policy, and the public imagination, 1958-1963. Isis 93: 183-205.

Zuckerkandl E, Pauling L. 1965. Molecules as documents of evolutionary history. J Theor Biol 8: 357-366. 


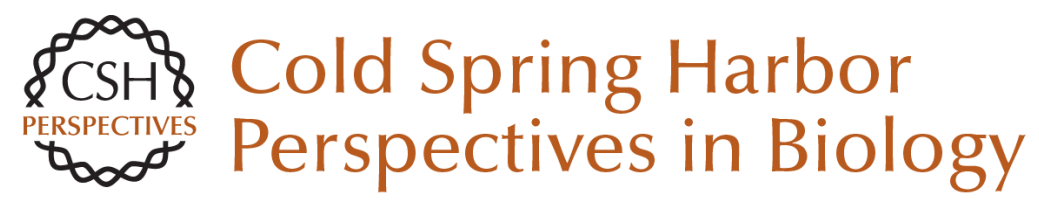

\title{
Historical Development of Origins Research
}

\author{
Antonio Lazcano
}

Cold Spring Harb Perspect Biol 2010; doi: 10.1101/cshperspect.a002089 originally published online June 9, 2010

\section{Subject Collection The Origins of Life}

\section{Constructing Partial Models of Cells} Norikazu Ichihashi, Tomoaki Matsuura, Hiroshi Kita, et al.

Ribonucleotides John D. Sutherland

Deep Phylogeny--How a Tree Can Help

Characterize Early Life on Earth Eric A. Gaucher, James T. Kratzer and Ryan N. Randall

Cosmic Carbon Chemistry: From the Interstellar Medium to the Early Earth Pascale Ehrenfreund and Jan Cami

\section{Origin and Evolution of the Ribosome} George E. Fox

\section{Planetary Organic Chemistry and the Origins of Biomolecules} Steven A. Benner, Hyo-Joong Kim, Myung-Jung Kim, et al.

Mineral Surfaces, Geochemical Complexities, and the Origins of Life Robert M. Hazen and Dimitri A. Sverjensky

Historical Development of Origins Research Antonio Lazcano
The Hadean-Archaean Environment Norman H. Sleep

An Origin of Life on Mars Christopher P. McKay

Primitive Genetic Polymers Aaron E. Engelhart and Nicholas V. Hud

Membrane Transport in Primitive Cells Sheref S. Mansy

The Origins of Cellular Life Jason P. Schrum, Ting F. Zhu and Jack W. Szostak

From Self-Assembled Vesicles to Protocells Irene A. Chen and Peter Walde

The Origin of Biological Homochirality Donna G. Blackmond

Earth's Earliest Atmospheres Kevin Zahnle, Laura Schaefer and Bruce Fegley

For additional articles in this collection, see http://cshperspectives.cshlp.org/cgi/collection/

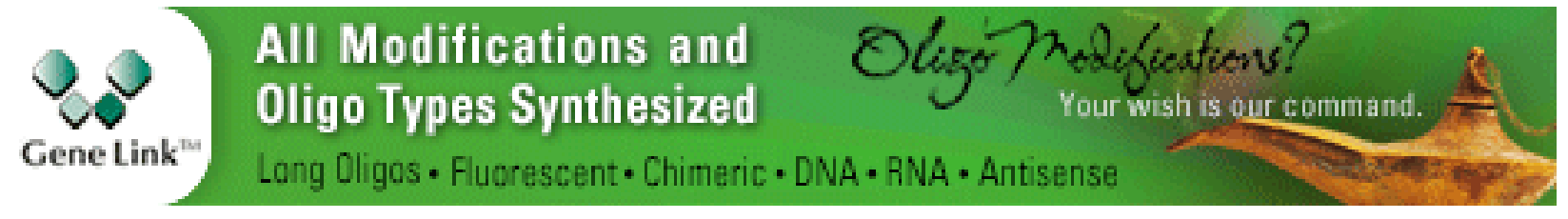

